\title{
Analisis Optimalisasi Sistem Solar Cell sebagai Energi Alternatif pada Pompa Air sebagai Pemenuhan Kebutuhan Air di Lahan Pertanian
}

\author{
Laillatul Qomaria $^{1^{*}}$, Sudarti $^{1}$ \\ ${ }^{1}$ Pendidikan Fisika, Fakultas Keguruan dan Ilmu Pendidikan, Universitas Jember \\ Jln, Kalimantan 37, Jember 68121 \\ *e-mail: lailatulqomariaa@gmail.com
}

Received: 02 Januari 2021. Accepted: 30 Januari 2021. Published: Februari 2021

\begin{abstract}
Abstrak
Semakin hari sumber daya fosil semakin berkurang, penggunaan bahan bakar fosil untuk pengairan di daerah persawahan juga berdampak pada pencemaran llingkungan, juga mahal biaya oprasionalnya. Untuk mengurangi masalah ini kami menawarkan energi alternatif sebagai pengganti dari energi fosil. Energi alternatif yang kami gunakan adalah energi yang bersumber dari matahari dengan panel surya. Panel surya dipasang dengan membentuk sudut agar intensitas cahaya matahari yang didapat lebih besar. Tegangan dan arus bergantung dengan intensitas cahaya matahari yang dihasilkan oleh panel surya, sehingga daya yang didapat juga besar. Rangkaian panel surya ditambah dengan SCC (Solar Charger Controller) agar tidak terjadi kelebihan pengisian daya dan juga menambah efisiensi kerja dari solar cell tersebut. Penggunaan solar cell ini sangat membantu para petani agar lebih hemat biaya oprasional dan juga ramah lingkungan. Waktu yang tepat untuk penyiraman adalah pada pagi dan sore hari saat arus yang dihasilkan mencapai maksimum, dan pengisian daya paling cocok dilakukan pada siang hari saat intensitas cahaya matahari dan daya yang dihasilkan mencapai maksimum.
\end{abstract}

Kata Kunci: tenaga surya, pompa air, lahan pertanian

\section{Analysis of Optimization of Solar Cell Systems as Alternative Energy in Water Pumps to Fulfill Water Needs in Agricultural Land}

\begin{abstract}
Day by day fossil resources are decreasing, the use of fossil fuels for irrigation in rice fields also has an impact on environmental pollution, and the operational costs are expensive. To reduce this problem we offer alternative energy instead of fossil energy. The alternative energy that we use is energy sourced from the sun with solar panels. Solar panels are installed by forming an angle so that the intensity of sunlight obtained is greater. Voltage and current depend on the intensity of sunlight produced by solar panels, so the power obtained is also large. The series of solar panels is added with SCC (Solar Charger Controller) so that there is no overcharging and also increases the work efficiency of the solar cell. The use of solar cells is very helpful for farmers to be more cost-effective and environmentally friendly. The right time for watering is in the morning and evening when the current generated reaches its maximum, and charging is best done during the day when the intensity of sunlight and power generated reaches the maximum.
\end{abstract}

Key words: solar power, water pump, farmland

\section{PENDAHULUAN}

Air digunakan oleh petani untuk mengairi lahan pertanian mereka karena jika kekurangan air atau pengairannya kurang baik maka hasil dari pertanian itu tidak dapat maksimal. Sehingga air merupakan komponen penting dalam 
pertanian. Lahan pertanian yang mengandalkan pengairan secara alami dengan membendung air dan mengilirkannya ke lahan sendiri dirasa kurang efektif untuk mendapatkan air yang cukup, dengan menggunakan diesel juga membutuhkan biaya yang lumayan besar serta tidak ramah lingkungan. Penawaran sistem untuk pengairan yang lebih ramah lingkungan dan hemat biaya adalah dengan menggunakan pompa air tenaga surya, hanya cukup mengandalkan sinar matahari sebagai energi penggeraknya tidak lagi menggunakan bahan bakar fosil yang tidak dapat diperbarui.

Di wilayah tropis cahaya matahari dapat diperoleh gratis sepanjang tahunnya. Salah satunya kita ambil contoh dikecamatan Dlingo, Kabupaten Bantul, terletak antara $07^{0}$ $44^{\prime} 04$ " LS dan $110^{\circ} 12^{\prime} 34^{\prime \prime}$ BT. Di wilayah ini saat musim kemarau cahaya matahari dapat diperoleh sepanjang hari, dan saat musim kemarau sebagian besar sumber air tanah hanya diperoleh dibeberapa tempat saja, namun kebutuhan air untuk lahan pertanian harus terus tercukupi. Pemanfaatan cahaya matahari untuk sumber energi listrik penggerak pompa air adalah energi yang ramah lingkungan dn juga terbarukan. Pompa air bekerja secara otomatis saat mendapatkan cahaya matahari yang cukup pada pagi hingga sore hari. Ketika cahaya matahari mulai berkurang hingga malam hari pompa otomatis akan berhenti bekerja. Demikian seterusnya, pompa air bekerja rata-rata selama 8 jam setiap hari dari pagi hingga sore untuk mengisi resevoir sesuai dengan kapasitas yang diperlukan.

Pemanfaatan energi matahari sangat tepat untuk daerah yang memiliki intensitas panas yang tinggi dan daerah persawahan yang jauh dari jangkauan arus listrik. Untuk merangcang energi matahari perlu diketahui terlebih dahulu kebutuhan daya alat-alat elektronik yang digunakan. Penggunaan pompa air dengan tenaga surya sebagai sumber energi listri penggeraknya sebagai cara penghematan energi fosil yang semakin menipis persediaanya, energi matahari adalah energi terbarukan dan ramah lingkungan. Sistem kerja dari pompa air tenaga surya adalah untuk memompa air pada ketinggian (head) dan jarak yang dibutuhkan pompa mendapatkan energi listrik dari panel surya.Pada waktu pagi sampai sore hari saat intensitas cahaya cukup, panel surya akan mengubah energi listrik, kemudian disimpan ke baterai sebagai sumber energi listrik untuk pompa air. Pemanfaatan energi matahari sangat tepat untuk daerah yang memiliki intensitas panas yang tinggi dan daerah persawahan yang jauh dari jangkauan arus listrik. Untuk merangcang energi matahari perlu diketahui terlebih dahulu kebutuhan daya alat-alat elektronik yang digunakan.

Berdasarkan ketetapan yang telah digunakan besarnya intensits penyinaran yang efektif yang telah ditetapkan sebagai parameter spesifikasi kinerja sel surya sebesar $1000 \mathrm{~W} / \mathrm{m}^{2}$ sebagai dasar ketetapan pada setiap spesifikasi sel surya. Perubahan suhu pada sel surya dapat mempengaruhi terjadinya perubahan besarnya tegangan (V) dan arus (I) pada kurva parameter sel surya sehingga pengaruh perubahan tersebut dapat berpengaruh pada daya output pada sel surya (Subandi, et al, 2019). Penggunaan energi surya ini sebagai sumberenergi listrik dapat menjamin ketersedian ssupply listrik yang ramah lingkungan untuk menggerakkan pompa air. Artikel ini bertujuan untuk mengetahui optimalisasi dari solar cell tersebut.

\section{METODE}


Metode yang dilakukan disini adalah dengan mereview beberapa artikel nasional dan internasional, untuk mendapatkan literasi data tentang pemanfaatan sel surya untuk pompa air dan juga mencari kelebihan-kelebihan dari sistem ini untuk alam dan juga untuk masyarakat. Dari beberapa jurnal itu kita bisa mengetahui intensitas cahaya yang cocok untuk sistem solar cell, cara pengoprasionalnya dan juga bisa memberikan kesimpulan dari solusi yang kami tawarkan. Untuk pengambilan data kami menggunakan dari jurnal yang kita review. Data yang diperlukan seperti intensitas cahaya matahari selama satu hari, tegangan dan arus, kemiringan modul dan juga waktu yang paling optimal untuk mendapatkan daya paling besar yang dihasilkan oleh solar cell tersebut. Agar efisien dari panel surya dapat diketahun, dan dapat mengetahui waktu yang cocok untuk pengisian daya dan juga waktu penyiraman.

\section{HASIL DAN PEMBAHASAN}

Air adalah kebutuhan pokok setiap mahluk hidup, air biasa digunakan untuk memenuhi kebutuhan hidup setiap harinya. Air juga digunakan pada lahan pertanian agar kebutuhan air dapat terpenuhi dengan baik, penyaluran air di lahan pertanian biasanya dengan aliran alami dari sungai-sungai kecil di sekitar lahan. Namun sistem ini kurang efektif, sehingga masyarakat banyak yang beralih ke teknologi modern seperti diesel untuk mengalirkan air ke lahan pertanian mereka. Penggunaan diesel ternyata juga memiliki kekurangan karena tidak ramah lingkuan dengan polusi yang dihasilkan, diesel juga masih menggunakan bahan bakar fosil sebagai tenaga pengggeraknya, yang mana semakin lama bahan bakar fosil ini juga semakin menipis persediannya karena tidak dapat diperbarui. Sebagai solusi dari permasalahan tersebut kami menawarkan sistem pompa air tenaga surya yang lebih ramah lingkungan, hemat bahan bakar fosil karena hanya menggunakan sinar matahari sebagai tenaga penggerak untuk mengalirkan air ke lahan pertanian.

Tenaga surya ini juga disebut dengan solar cell, penerapan teknologi ini adalah dengan memanfaatkan panel surya sebagai alat konversi energi matahari menjadi energi listrik untuk sumber listrik pada pompa air. Panel surya ini merupakan elemen aktif yang dapat mengubah cahaya matahari menjadi energi listrik. Fungsi dari Solar panel adalah untuk menerima panas matahari dan mengubahnya menjadi aliran listrik DC. Listrik tersebut kemudian masuk kedalam inventer untuk diubah menjadi arus AC dan selanjutnya digunakan untuk menggerakkan pompa. Air yang dipompa tidak langsung diaalirkan kelahan pertanian, namun disimpan di dalam bak penampung yang terdapat dilahan terlebih dahulu baru kemudian dialirkan ke lahan pertanin sesuai jadwal sebagai air irigasi. Hal tersebut dilakukan jika pada rangkaian panel suryanya tidak dipasang SCC (Solar Charger Controller). Intensitas cahaya matahari yang diterima menentukan besar-kecilnya daya output solar panel yang dihasilkan.

Pada dasarnya prinsip kerja dari panel surya adalah ketika cahaya matahari mengenai panel surya, maka elektron-elektron yang ada pada panel surya akan bergerak dari $\mathrm{N}$ (negatif) ke $\mathrm{P}$ (positif), sehingga pada terminal keluaran dari panel surya akan menghasilkan energi listrik. Jumlah sel surya yang digunakan dan dikombinasikan pada panel surya berpengaruh pada besarnya energi listrik yang dihasilkan oleh panel surya tersebut, sehingga daya pada setiap panel surya berbeda-beda. 
Pompa air akan bekerja secara otomatis ketika intensitas cahaya matahari yang dirasa cukup untuk menggerakkan pompa air tersebut terpenuhi yaitu saat pagi hingga sore hari. Namun ketika semakin sore intensitas cahaya mataharipun semakin berkurang hingga pada saat malam hari, pompa air akan berhenti bekerja dengan sendirinya. Demikian seterusnya pompa air akan bekerja selama rata-rata 8 jam dalam sehari untuk mengisi resevoir sesuai dengan kapasitas yang diperlukan. Jika tidak menggunakan SCC (Solar Charger Controller) karena ditakutkan terjadi kelebihan daya pada baterai yang akan mempercepat kerusakan pada baterai. Maka tidak direkomendasikan untuk menyimpan energi listrik dalam battery (aumulator), tetapi direkomendasikan menyimpan air dalam bak penampung yang biasanya dipasang di sekitar lahan.

Rangkai meja atau tempat panel suryanya berdasarkan jumlah panel surya yang digunakan. Besarnya intensitas radiasi matahari yang diterima atau jatuh pada permukaan panel surya ditentukan dari kemiringan panel tersebut saat dipasang. Output daya yang dihasilkan oleh panel surya bergantung pada besarnya intensitas radiasi matahari. Ketika intensitas matahari mencapai maksimum maka panel juga dapat meksimum untuk menyalakan pompa air.

Ketika matahari mencapai kondisi maksimum $1000 \mathrm{~W} / \mathrm{m}^{2}$ total daya listrik yang dihasilkan oleh panel surya dalam dapat mencapai 200 watt (2 $\times 100$ watt), dengan daya sebesar itu memungkinkan untuk memutar 2 unit pompa air celup. Untuk memudahkan perawatan secara berkala pada panel surya maka panel surya dipasang pada meja dudukan yang tidak permanen agar mudah dilepas saat dilakukan perawatan ataupun perbaikan. Pada panel suryaa terdapat kabel listrik DC dengan 2 kabel keluaran (output) yang terdiri dari kabel positif (+) dan kabel negatif (-), sama halnya dengan kebel masukan (input) juga terdapat 2 kabel keluaran (output) yang terdiri dari kabel positif (+) dan kabel negatif (-).

Data penelitian dari jurnal yang kami review tentang pengaruh sudut datang matahari terhadap keluaran sel surya, bertujuan untuk mengetahui seberapa besar pengaruh sudut datang matahari pada optimalisasi kerja panel surya.

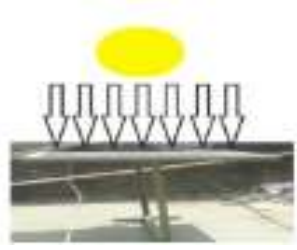

(a)

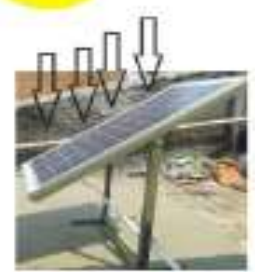

(b)
Gambar 1. Tampilan Sinar Matahari terhadap Sudut

Pada gambar (a) panel sel surya dipasang untuk mengetahui keluaran maksimum dengan posisi panel sel surya tegak lurus terhadap arah sinar matahari, sedangkan pada gambar (b) panel sel surya dipasang untuk mengetahui pengaruh arah sinar matahari terhadap keluaran panel, dengan posisi panel sel surya dengan kemiringan arah $10^{0}$ sampai mencapai sudut $45^{\circ}$.

Pergerakan sudut matahari pada selang waktu tertentu selalu mengalami perubahan untuk mengetahui seberapa besar pergerakan tersebut maka sangat diperlukan pengambilan data posisi/sudut. Pengambilan data tersebut dilakukan pada jam 08:00 sampai jam 16:00. Sehingga menghasilkan data seperti tabel 1 dibawah ini: 
Tabel 1. Data Hasil Pengukuran pada Pukul 08:00 sampai Pukul 16:00

\begin{tabular}{cccccccc}
\hline \multirow{2}{*}{ No } & \multirow{2}{*}{ Jam } & \multicolumn{3}{c}{ Posisi Tegak Lurus } & \multicolumn{3}{c}{ Posisi Bentuk Sudut } \\
\cline { 3 - 7 } & & Voc & $\mathrm{I}$ & $\mathrm{P}$ & Voc & $\mathrm{I}$ & $\mathrm{P}$ \\
\hline 1 & $08: 00$ & 20,4 & 1,00 & 16,53 & 20,7 & 1,40 & 23,53 \\
2 & $09: 00$ & 20,9 & 1,05 & 17,84 & 20,0 & 2,57 & 41,53 \\
3 & $10: 00$ & 19,3 & 1,81 & 28,05 & 18,8 & 3,05 & 45,81 \\
4 & $11: 00$ & 19,5 & 2,08 & 32,61 & 18,2 & 3,05 & 44,13 \\
5 & $12: 00$ & 19,0 & 1,97 & 29,94 & 18,3 & 3,05 & 44,37 \\
6 & $13: 00$ & 18,0 & 2,08 & 29,68 & 18,3 & 3,05 & 44,37 \\
7 & $14: 00$ & 19,0 & 0,97 & 14,74 & 19,3 & 2,87 & 44,48 \\
8 & $15: 00$ & 20,7 & 0,85 & 14,28 & 20,0 & 2,05 & 33,13 \\
9 & $16: 00$ & 20,2 & 0,83 & 13,56 & 10,8 & 1,35 & 22,83 \\
\multicolumn{2}{c}{ Rata-rata } & 19,67 & 1,40 & 21,91 & 18,27 & 2,49 & 38,24 \\
\hline
\end{tabular}

Voc $=$ Tegangan $(\mathrm{V}) ; \mathrm{I}=$ Arus $(\mathrm{A}) ; \mathrm{P}=$ Daya $\operatorname{Keluar}(\mathrm{W})$

Dari tabel 1 diatas dapat kita ketahui bahwa rata-rata dari tegangan hubungan singkat pada saat modul surya dalam posisi tegak lurus dengan sinar matahari (horizontal) sebesar 19,67V dan diperoleh nilai pengukuran rata-rata tegangan rangkaian terbuka pada modul surya dalam posisi membentuk sudut sebesar $18,27 \mathrm{~V}$. Perbedaan nilai dari tegangan rangkaian terbuka (Voc) karena pada keadaan tegak lurus posisinya akan tetap sama terhadap matahari berbeda dengan saat membentuk sudut sehingga hasinya lebih besar yang dalam posisi tegak lurus terhdap matahari.

Pada arus posisi modul surya dengan sudut menghasilkan nilai ratarata yang lebih besar yaitu 2,49A dibandingkan dengan posisi modul surya yang tegak lurus dengan nilai rata-rata sebesar $1,40 \mathrm{~A}$ dengan sifat statis. Karena iradiasi yang ditangkap modul surya pada posisi membentuk sudut lebih besar dari yang posisi tegak lurus sehingga arus yang ditangkap lebih besar, sehingga terbentuklah sifat statis tersebut. Setelah diketahui nilai tegangan dengan posisi tegak lurus dan membentuk sudut kita bisa mendapatkan nilai dari tegangannya, dimana nilai tegangan dengan posisi membentuk sudut lebih besar dibandingkan dengan posisi tegak lurus. Sehingga pemasangan modul surya dengan posisi membentuk sudut lebih efektif untuk menggerakkan pompa air.

Pada sebuah penelitian lain menentukan nilai intensitas matahari yang paling optimal dalam satu hari terjadi dari jam 06:00 sampai jam 17:00, modul surya dipasang dengan membentuk sudut dan menghasilkan data sebagai berikut:

Tabel 2. Data Hasil Pengukuran pada Pukul 06:00 sampai Pukul 17:00

\begin{tabular}{ccccc}
\hline No & Waktu & Maks & Min & Rata-rata \\
\hline 1 & $06: 00$ & 570 & 606 & 588 \\
2 & $07: 00$ & 1520 & 1100 & 1310 \\
3 & $08: 00$ & 9080 & 7820 & 8450 \\
4 & $09: 00$ & 47600 & 23120 & 35360 \\
5 & $10: 00$ & 95200 & 76000 & 85600
\end{tabular}


Analisis Optimalisasi Sistem...Jupiter... Vol 2 No 2...Februari 2021...58-65

Laillatul Qomaria, Sudarti

\begin{tabular}{ccccc}
6 & $11: 00$ & 130762 & 128920 & 129841 \\
7 & $12: 00$ & 120300 & 112300 & 116300 \\
8 & $13: 00$ & 82500 & 56700 & 69600 \\
9 & $14: 00$ & 59600 & 43200 & 51400 \\
10 & $15: 00$ & 32000 & 15070 & 23535 \\
11 & $16: 00$ & 9010 & 6970 & 7990 \\
12 & $17: 00$ & 5700 & 2480 & 4090 \\
\hline
\end{tabular}

Dari data tabel 2 di atas sudah diketahui nilai maksimal, minimal dan rata-rata dari intensitas cahaya matahari dalam satuan xIIux. Puncak intensitas cahaya matahari paling optimal berkisar antara jam 10:00 sampai jam 13:00, namun yang paling tinggi terjadi pada jam 11:00 dan 12:00.

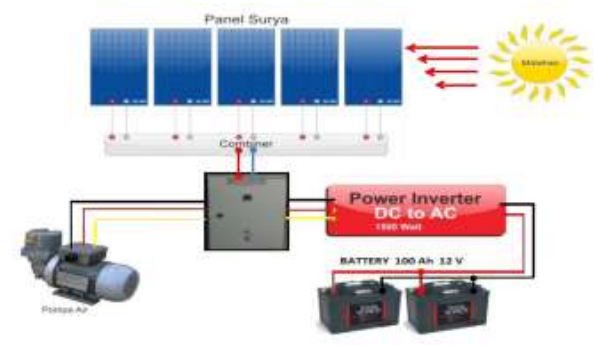

\section{Gambar 2. Cara Kerja Solar Cell}

Solar cell yang digunakan adalah polycrystalline, dengan daya keluaran 100Wp dan ukuran panel suryanya $0,75 \mathrm{M}$, serta intensitas cahaya matahari maksimim $1000 \mathrm{~W} / \mathrm{m}^{2}$. Penstabilisasian solar cell untuk menggerakkan pompa air, sebuah penelitian dari jurnal yang kami review menambahkan solar charger controller (SCC) agar baterai tidak mudah rusak karena over-charging dan ketidak stabilan tegangan. Hasil pengujian PLTS didapat bahwa tegangan keluaran dari solar charger lebih stabil yaitu sekitar 13,6V dibandingkan dengan tegangan keluaran rata-rata dari panel surya sekitar 15,8V-17,3V. Ini terjadi karena didalam solar charger coltroller (SCC) terdapat rangkaian pengatur tegangan dan arus dan oleh karena itu pengisian baterai pada setiap jamnya akan selalu stabil, sehingga tidak terjadi over charging, dan keadaan ini akan sama setiap jamnya. Jadi walaupun panel surya menghasilkan tegangan nominal $17,3 \mathrm{~V}$, tegangan pengisian baterai akan tetap stabil yaitu sekitar 13,6 V. Ini bertujuan agar baterai tidak mudah rusak, dibandikan dengan panel surya yang langsung dihubungkan ke baterai tanpa melewati SCC. Berikut tabel data pengukuran arus dan tegangan panel surya:

Tabel 3. Data Pengukuran Arus dan Tegangan Panel Surya

\begin{tabular}{cccccc}
\hline No & Waktu & \multicolumn{2}{c}{ Output panel surya } & \multicolumn{2}{c}{ Output charger controller } \\
\cline { 3 - 6 } & & V (volt) & I (ampere) & V (volt) & I (ampere) \\
\cline { 3 - 6 } 1 & $06: 00$ & 16,2 & 1 & 13,8 & 1 \\
2 & $07: 00$ & 17 & 3,5 & 13,5 & 3,5 \\
3 & $08: 00$ & 17,2 & 4 & 13,5 & 4 \\
4 & $09: 00$ & 17,2 & 4 & 13,6 & 4 \\
5 & $10: 00$ & 17 & 5 & 13,7 & 5 \\
6 & $11: 00$ & 17,2 & 4,5 & 13,7 & 4,5 \\
7 & $12: 00$ & 17,2 & 4,5 & 13,7 & 4,5 \\
8 & $13: 00$ & 17,3 & 5 & 13,7 & 5 \\
9 & $14: 00$ & 17 & 4,5 & 13,6 & 4,5
\end{tabular}




\begin{tabular}{llllll}
10 & $15: 00$ & 16,9 & 3 & 13,5 & 3 \\
11 & $16: 00$ & 16,4 & 2 & 13,5 & 2 \\
12 & $17: 00$ & 15,8 & 1 & 13,5 & 1 \\
\hline
\end{tabular}

Tingkat intensitas dari radiasi matahari sangat pempengruhi proses pengisian atau kinerja dari pomp air. Dari tabel diatas daya tertinggi dihasilkan panel surya saat pengukuran terjadi pada tegangan $17,3 \mathrm{~V}$ dan arus 5A. ketika tegangan pada baterai sudah mencapai tegangan maksimum yaitu 13,6 V maka secara otomatis arus yang mengalir ke baterai akan berhenti sehingga kemungkinan terjadinya pengisian yang berlebih (over charging) tidak akan terjadi. Efisiensi dari penggunaan panel serya sangat bergantung pata daya yang dihasilkan terangan, arus dan juga luas penampang.

- $\eta=$ efisiensi panel surya

- $\mathrm{A}=$ luas penampang panel surya

- $\mathrm{I}=$ arus

- $\mathrm{V}=$ tegangan

- Pout = paya keluaran $50 \mathrm{Wp}$

Pada saat arus dan tegangan maksimum, maka efisiensi yang didapat juga besar dan maksimum. Perhitungannya diberikan sebagai berikut:

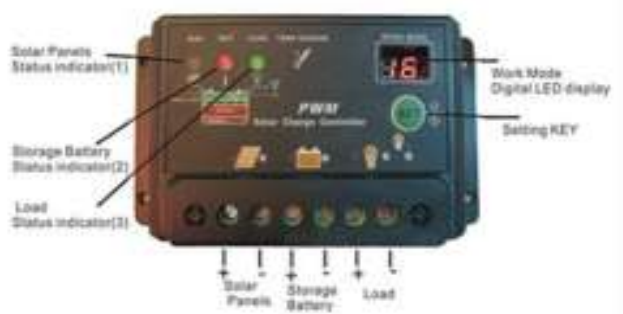

$\eta=\frac{V \cdot I}{P \cdot A} 100 \%$

$\eta=\frac{13,7 \times 5}{100 \times 0,75} 100 \%$

$\eta=\frac{68,5}{75} 100 \%$

$\eta=91,33 \%$

$\begin{array}{ccr}\text { Pada } & \text { jurnal } & \text { sebelumnya } \\ \text { dijelaskan } & \text { bahwa } & \text { tidak }\end{array}$
direkomendasikan untuk menyimpan energi listrik dalam battery (aumulator), tetapi direkomendasikan menyimpan air dalam tangki penampung/tandon air (resevoir). Namun dalam jurnal lain kita mendapatkan solusi dari masalah itu, yaitu dengan menambahkan SCC (Solar Charger Controller). SCC menerapkan teknologi pluse widh modullation (PWM) untuk mengatur fungsi pengisian baterai dan pembebasan arus dari baterai ke beban. Beban berupa pompa air jet pump beroperasi, disuplay dengan menggunakan sumber tegangan bolak-balik (AC). Pompa air dan sumber tegangan diberikan pada Gambar 3.

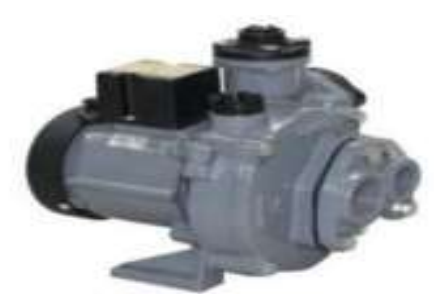

Gambar 3. Sumber Tegangan dan Pompa Air

Intensitas cahaya matahari berbanding lurus dengan tegangan, arus, daya, serta efisiensi dari panel surya yang dihasilkan. Dengan adanya panel surya uini bisa lebih menghemat dana untuk pengairan air, hemat biaya operasionl dan juga lebih ramah lingkungan. Pada siang hari saat intensitas cahaya matahari maksimum maka tegangan dan arus yang dihasilkan juga besar sehingga sangat cocok untuk pengisian daya atau enegi pada baterai dengan juga menggunakan SCC (Solar Charger Controller) agar tidak terjadi keelebihan pengisian dan baterai juga tahan lebih lama. Untuk penyiraman cocok dilakukan pada pagi dan sore hari saat arusnya mencapai maksimum.

\section{KESIMPULAN}


Kemiringan panel surya berpengruh pada tegangan dan arus yang dihasilkan pada saat panel surya dalam kondisi tegak lurus menghasilkan tegangan rata-rata sebesar $19,6 \mathrm{~V}$ dan arus rata-rata sebesar $1,40 \mathrm{~A}$, sedangkan pada saat panel surya dalam kondisi membentuk sudut menghasilkan tegangan rata-rata sebesar $18,27 \mathrm{~V}$ dan arus rata-rata sebesar 2,49A, sehingga agar mendapatkan daya yang besar lebih baik dipasang dengan membentuk sudut. Intensitas cahaya matahari maksimum dihasilkan pada saat siang hari, dan dengan semakin besarnya intensitas cahaya matahari maka semakin besar pula nilai tegangan dan arusnya. Agar baterai pada sistem pembangkit tenaga surya tidak mudah rusak maka ditambahkan SCC (Solar Charger Controller) agar tidak terjadi kelebihan pengisian dan menambah efisiensi dari panel surya. Pengisian baterai sangan cocok dilakukan pada siang hari dan penyiraman atau pengairan baik dilakukan di pagi dan sore hari. Sistem ini sangat membantu petani untuk mengairi lahan pertanian mereka denga biaya yang lebih murah dan juga ramah lingkungan.

\section{DAFTAR PUSTAKA}

Pulungan, A B. Juli Sardi. Hamdani. Hastuti. 2019. Pemasangan Sistem Hybrid Sebagai Penggerak Pompa Air. JTEV (Jurnal Teknik Elektro dan Vokasional). 5(2), 35-44.

Joubrert, at al. 2016. Kinerja Jaringan Irigasi Air Tanah Pada Irigasi Hemat Air Berbasis Pompa Air Tenaga Surya. Jurnal Irigasi. 11(5), 125-132.

Suyanto, Muhammad. 2017. Pengaruh Pengguunaan Solar Charger Controler Terhadap Stabilitas Slolar Cell Sebagai Penyuplay Pompa Air Pada Kebun Salak
Dimusim Kemarau. SNST. 8(2), 12-17.

Hartono, Budi. dan Purwanto. 2015. Perancangan Pompa Air Tenaga Surya Guna Memindahkan Air Bersih Ke Tangki Penampungan. SINTEK. 9(1), 2088-9038.

Rozaq, et al. 2019. Implementasi Teknologi Pompa Air Tenaga Surya Di Desa Karyabaru Kecmatan Barambai Kabupaten Barito Kuala. Jurnal Impact (Implementation and Action). 1(2), 92-109.

Subandi, et al. 2019. Penggerak Pompa Air Dengan Tenaga Solar Cell Untuk Meningkatkan Pertanian Cabe. SNT (Seminar Nasional Teknoka). 4(4), 2502-8782.

Iqtimal, et al. 2018. Aplikasi Sistem Tenaga Surya Sebagai Sumber Tegangan Listrik Pompa Air. Jurnal Online Teknik Eloktro. 3(1), 2252-7036.

Ramadhan, et al. 2016. Analisis Desain Sistem Pembangkit Listrik Tenaga Surya Kapasitas 50 WP. Jurnal Teknik. 37(2), 59-63.

Jaelani, Otong. dan Heri Suripto. 2020. Analisis Performan Dan Nilai Ekonomi Sistem Solar Cell Untuk Pengoperasian Pompa Air dengan Metode Eksperimental. Jurnal Rekayasa Mesin. 15(1), 42-50.

Zainuddin, M. dan Muhammad Darmawan. 2017. Pemanfaatan pompa Air Tenaga Surya (PATS) untuk Irigasi Lahan Sawah Di Kulurahan Tanggikiki Kota Gorontalo. Jurnal Impact (Implementation and Action) 8(2), 151-158. 